\title{
PENGHITUNGAN DATA STOK KAPITAL DENGAN METODE PERPETUAL INVENTORY (PIM) (Suatu Upaya Penyediaan Data Stok Kapital untuk Penghitungan Potensial Output dengan Pendekatan Fungsi Produksi) *)
}

\author{
Gunawan Wicaksono, Eko Ariantoro, dan A. Reina Sari **)
}

\begin{abstract}
Upaya penyediaan data stok kapital oleh Bank Indonesia semata-mata didasarkan pada kebutuhan untuk menghitung output gap antara output potensial dengan output riilnya. Output gap tersebut merupakan salah satu variabel penting dalam model ekonomi makro yang saat ini sedang dikembangkan oleh BI. Dalam jangka pendek, estimasi output gap memberikan informasi mengenai sumber-sumber tekanan inflasi, sementara dalam jangka panjang, estimasi output potensial memberikan sinyal mengenai tingkat produksi yang diperlukan guna mencapai sustainable economic growth.
\end{abstract}

Secara umum, stok kapital didefinisikan sebagai persediaan berbagai jenis barang modal, seperti bangunan, mesinmesin, alat transportasi, ternak, dan barang modal lainnya, yang memberikan kontribusi terhadap kelangsungan suatu proses produksi. Dalam prakteknya, data stok kapital tersebut menggambarkan posisi barang modal yang terbentuk dari suatu proses akumulasi investasi dalam jangka waktu tertentu. Dalam terminologi SNA 1968, investasi tersebut dikenal sebagai Gross Fixed Capital Formation atau Pembentukan Modal Tetap Bruto (PMTB).

Beberapa negara seperti Belanda, Inggris, Jerman, Australia dan Kanada telah memiliki data stok kapital sejak lama, baik yang dihitung dengan metode langsung maupun metode tidak langsung. Sementara di Indonesia, ketersediaan informasi mengenai stok kapital masih terbatas pada pemanfaatan proxy variable berupa data investasi. Meskipun demikian, beberapa upaya penelitian stok kapital telah dilakukan, antara lain oleh Keuning (1988 dan 1991), Badan Pusat Statistik (1995), dan Timmer (1999).

Pada tahun 2000, BI melakukan kajian mengenai kemungkinan pengumpulan data stok kapital sektor industri pengolahan. Hasil kajian tersebut merekomendasikan bahwa metode PIM merupakan metode penghitungan stok kapital yang tepat digunakan saat ini. Dengan metode ini, stok kapital dihitung menggunakan data investasi yang tersedia. Proses penghitungan stok kapital tersebut diimplementasikan pada tahun 2001 yang dilaksanakan bekerjasama dengan BPS.

Hasil penghitungan stok kapital disusun dalam bentuk data time-series periode 1980-2000 dan disajikan dalam 2 (dua) konsep, yaitu stok kapital bruto (Gross Capital Stock/GCS) dan stok kapital neto (Net Capital Stock/NCS). Dalam periode tersebut, baik GCS maupun NCS senantiasa mengalami pertumbuhan positif dengan pertumbuhan rata-rata per tahun (yearly average) sebesar 3,4\%. Krisis ekonomi sejak pertengahan tahun 1997 tercermin pada melambatnya pertumbuhan NCS pada tahun 1998 menjadi sebesar 0,8\% dan kontraksi pada tahun 1999 sebesar 1,2\%.

*) Tulisan ini merupakan hasil kegiatan Program Kerja (PK) Strategis Direktorat Statistik Ekonomi dan Moneter tahun 2001 yaitu "Menyusun Data Stok Kapital dengan Metode Perpetual Inventory (PIM)".

**) Para peneliti ekonomi di Bagian Statistik Sektor Riil dan Keuangan Pemerintah, Direktorat Statistik Ekonomi dan Moneter, Bank Indonesia 


\section{TINJAUAN UMUM DAN LATAR BELAKANG}

Tujuan Bank Indonesia sejak diberlakukannya Undang-Undang Nomor 23 Tahun 1999 difokuskan pada tujuan tunggal (single objective) yaitu mencapai dan memelihara kestabilan nilai rupiah, baik terhadap barang dan jasa yang tercermin pada laju inflasi maupun terhadap mata uang negara lain yang tercermin pada nilai tukar. Hal ini menuntut Bank Indonesia untuk lebih mengkonsentrasikan pelaksanaan tugas-tugasnya dalam pengendalian moneter untuk mencapai tujuan tunggal Bank Indonesia, yaitu nilai rupiah yang stabil. Dalam rangka pelaksanaan tugas pengendalian moneter, Bank Indonesia menetapkan sasaran-sasaran moneter dengan memperhatikan sasaran laju inflasi yang akan dicapai dalam suatu periode tertentu. Kebijakan yang diarahkan pada pencapaian sasaran tunggal berupa laju inflasi yang stabil dan upaya kebijakan yang diperlukan untuk mencapai sasaran tunggal (single target) inilah yang kemudian dikenal sebagai kerangka kebijakan inflation targeting. Di beberapa negara maju seperti Inggris, Canada, Australia dan New Zealand, inflation targeting telah sejak lama diterapkan sebagai kerangka kebijakan dalam rangka pengendalian moneter.

Beberapa pertimbangan penting menjadi dasar bagi diimplementasikannya kerangka kebijakan inflation targeting dimana inflasi menjadi sasaran akhir suatu kebijakan moneter. Pertama, bukti-bukti empiris menunjukkan bahwa dalam jangka panjang kebijakan moneter hanya dapat berpengaruh pada tingkat inflasi dan sebaliknya tidak dapat mempengaruhi variabel-variabel rill seperti pertumbuhan ekonomi maupun pengangguran. Dengan kata lain bahwa kebijakan moneter hanya dapat mempengaruhi variabel-variabel rill dalam jangka pendek. Kedua, meskipun tidak selalu terjadi pada semua negara, secara umum pencapaian inflasi yang rendah merupakan prasyarat bagi tercapainya pertumbuhan yang berkelanjutan (sustainable economic growth), karena perekonomian tidak dipacu untuk tumbuh melebihi kapasitasnya. Ketiga, dengan menetapkan inflasi sebagai sasaran tunggal, maka sasaran inlasi tersebut akan menjadi jangkar nominal dalam merumuskan setiap kebijakan moneter.

Dalam pelaksanaannya, kerangka kebijakan inflation targeting mensyaratkan adanya suatu angka prediksi inflasi yang akurat. Angka prediksi inflasi tersebut tentunya hanya dapat diperoleh apabila terdapat variabel-variabel antara yang reliable. Dalam rangka meningkatkan akurasi prediksi angka inflasi tersebut, Bank Indonesia sedang membangun suatu model struktural untuk memproyeksikan kondisi ekonomi makro, termasuk proyeksi angka inflasi. Berbagai indikator ekonomi yang relevan sangat diperlukan untuk membangun model ekonomi tersebut, seperti nilai tukar, suku bunga, harga saham, tingkat pengangguran, stok kapital dan data perkembangan agregat ekonomi lainnya.

Permasalahan yang seringkali muncul adalah bahwa tidak semua indikator ekonomi tersedia dengan baik di Indonesia, misalnya data stok kapital. Ketersediaan informasi yang 
berkaitan data stok kapital masih terbatas pada pemanfaatan data investasi sebagai proxi untuk mensubstitusi kebutuhan data stok kapital. Beberapa upaya penelitian mengenai stok kapital pernah dilakukan, yaitu oleh Keuning (1988 dan 1991), Badan Pusat Statistik (1995), dan Timmer (1999). Namun demikian, hasil penelitian tersebut sampai saat ini belum dapat dipublikasikan secara resmi karena berbagai pertimbangan.

Sehubungan dengan hal tersebut, Bank Indonesia bekerjasama dengan BPS melakukan upaya penyempurnaan penghitungan stok kapital, sehingga diperoleh data stok kapital yang akurat dan dapat dipercaya yang pada gilirannya dapat dimanfaatkan oleh Bank Indonesia sendiri maupun oleh pengguna data yang lain seperti BPS, Bappenas dan Lembaga Penelitian lainnya. Dalam tulisan ini akan dibahas mengenai prosedur penyusunan data stok kapital mulai dari proses pengumpulan data sampai dengan teknis penghitungannya.

\section{Latar Belakang Penghitungan Stok Kapital}

Secara teoritis, Bank Sentral yang menganut kebijakan inflation targeting akan senantiasa berpedoman pada suatu mekanisme transmisi kebijakan moneter dimana kesenjangan keluaran (output gap) dan inflasi inti (core inflation) masing-masing ditetapkan sebagai sasaran implisit dan eksplisit. Dalam hal ini kebijakan moneter Bank Sentral difokuskan pada upaya menyelaraskan (aligning) sasaran implisit yang ditunjukkan dengan ekspektasi pelaku pasar dengan sasaran implisitnya yaitu ekspektasi Bank Sentral. Indikator output gap akan menunjukkan seberapa besar output yang harus dikorbankan dalam rangka mengendalikan tingkat inflasi ke arah sasaran yang ingin dicapai.

Keterlibatan Bank Indonesia dalam upaya penghitungan stok kapital semata-mata dikarenakan kebutuhan BI untuk melihat kesenjangan output (output gap) yang terjadi karena adanya selisih antara output potensial dengan output riilnya. Dilihat dari sisi penawaran, konsep mengenai output potensial adalah output maksimum yang dihasilkan suatu ekonomi tanpa menimbulkan tekanan inflasi. Hal ini terjadi karena sumber daya yang tersedia diproduksi sebatas kapasitas yang dimiliki. Dalam jangka pendek, estimasi output gap antara output rill dengan output potensial memberikan informasi mengenai sumber-sumber tekanan inflasi. Sementara itu dalam jangka panjang, estimasi output potensial memberikan sinyal mengenai tingkat produksi yang diperlukan guna mencapai sustainable economic growth.

Untuk menghitung output potensial, terdapat dua pendekatan yang sering digunakan di negara-negara maju, yaitu pendekatan menggunakan model struktural fungsi produksi dan pendekatan menggunakan perangkat ekonometri (univariate techniques). Dari kedua pendekatan tersebut, pendekatan fungsi produksi lebih banyak digunakan dibandingkan menggunakan perangkat ekonometri. Melalui pendekatan fungsi produksi Cobb-Douglass, variabel stok kapital (productive capital stock) bersama-sama dengan variabel tenaga kerja 
(productive employment) digunakan untuk memperkirakan nilai output potensial, sementara output riilnya diestimasi dengan menggunakan angka Produk Domestik Bruto (PDB). Dari variabel-veariabel yang diperlukan untuk menghitung output gap tersebut, data stok kapital masih belum tersedia dengan baik.

Berdasarkan hasil penelitian mengenai kemungkinan pengumpulan data stok kapital $^{* * *}$ telah disimpulkan bahwa untuk sementara ini dapat dilakukan penyusunan data stok kapital dengan menggunakan metode Perpetual Inventory (PIM). Metode ini dipilih terutama karena keunggulannya berupa efisiensi biaya dan sumber daya manusia yang diperlukan.

\section{Beberapa Pendekatan Penghitungan Stok Kapital}

Tidak diketahui secara pasti negara mana yang pertama kali melakukan penghitungan stok kapital. Hanya saja, negara-negara maju di Eropa seperti Belanda, Inggris dan Jerman, serta di Australia dan Canada telah memiliki data stok kapital sejak lama, meskipun dengan metode penghitungan yang berbeda-beda. Secara umum, terdapat dua pendekatan untuk menyusun data stok kapital, yaitu metode lansung dan metode tak langsung. Dengan menggunakan metode langsung, data stok kapital disusun atas dasar data yang dikumpulkan secara langsung dari laporan keuangan perusahaan ataupun administrasi pemerintahan, sedangkan metode tak langsung lebih menfokuskan pada penggalian data sekunder yang tersedia dan penetapan asumsi-asumsi yang digunakan.

Setidaknya terdapat tiga metode penghitungan yang dikategorikan sebagai metode langsung, yaitu Fixed Asset Accounting Simulation Model (FAASM), Direct Observation of Capital (DOC), dan Anchored FAASM. Dari ketiga metode tersebut, metode FAASM yang dikembangkan oleh Jaffey pada tahun 1990 merupakan metode langsung yang paling menyeluruh (integrated direct method) karena mampu menghasilkan data statistik stok kapital dengan kategori dan dimensi yang paling luas. Dengan menggunakan metode ini, data umur aset (asset life) dan pola distribusi (discard pattern) bukan diasumsikan sebagaimana penghitungan dengan metode tidak langsung, melainkan ditentukan dari keadaan yang sesungguhnya melalui pengamatan secara langsung. Metode DOC dilakukan melalui survei, dimana data aset perusahaan dikumpulkan atas dasar historical cost. Oleh sebab itu, akurasi DOC sangat tergantung pada kualitas prosedur akuntansi perusahaan. Sementara itu, metode Anchored FAASM merupakan kombinasi antara metode FAASM dan DOC dimana data yang dikumpulkan melalui survei digunakan untuk memperbaiki data hasil penghitungan menggunakan metode FAASM.

Metode DOC merupakan metode langsung yang lebih banyak digunakan dibandingkan metode langsung lainnya. Disamping karena metode FAASM dan Anchored FAASM yang 
masih relatif baru, tetapi juga karena keunggulan yang dimiliki metode DOC, yaitu tingkat akurasi data investasi serta asset life dan discard pattern setiap jenis aset yang dapat diketahui secara langsung. Adanya upaya untuk mendapatkan data stok kapital yang lebih reliable menyebabkan metode pengukuran DOC disarankan untuk digunakan menggantikan metode PIM. Namun demikian, implementasi metode DOC seringkali terhambat karena metode ini membutuhkan biaya yang sangat besar dan sumber daya manusia yang memadai baik dari segi skill maupun jumlahnya.

Sebaliknya, metode tak langsung biasanya digunakan oleh negara-negara yang karena berbagai alasan tidak dapat melaksanakan survei secara langsung ke perusahaanperusahaan. Metode tak langsung yang banyak digunakan adalah metode PIM, yaitu penghitungan stok kapital yang dilakukan dengan cara memanfaatkan data sekunder yang tersedia, seperti data Pembentukan Modal Tetap Bruto/PMTB (Gross Fixed Capital Formation/ GFCF). Dua syarat mutlak agar metode PIM menghasilkan angka yang reliable adalah tersedianya data PMTB yang dapat dipercaya dengan kategori yang rinci dan cakupan data yang luas serta penetapan asumsi yang digunakan.

\section{Pendekatan Penghitungan yang Dilakukan Saat ini: Perpetual Inventory Method (PIM)}

Berbeda dengan metode DOC yang biayanya mahal, penggunaan metode PIM dalam pengukuran stok kapital hanya membutuhkan relatif lebih sedikit biaya dan sumber daya manusia. Kelebihan metode PIM lainnya adalah bahwa proses input data relatif lebih sedikit. Disamping itu, hambatan birokrasi yang sering terjadi dalam pengumpulan data secara langsung tidak ditemui pada metode PIM. Adapun kelemahan yang paling mendasar pada metode PIM adalah lemahnya akurasi hasil perhitungan stok kapital dibandingkan dengan metode langsung. Kelemahan metode PIM lainnya adalah bahwa hasil estimasi stok kapital sangat sensitif terhadap asumsi umur aset, pola distribusi dan metode depresiasi yang digunakan.

Dengan mempertimbangkan kelebihan dan kelemahan antara metode DOC dengan metode PIM, maka sebagai langkah awal pengukuran stok kapital dapat dilakukan dengan menggunakan metode PIM. Untuk meningkatkan kualitas hasil perhitungan stok kapital, hal-hal yang perlu dilakukan adalah memperbaiki data investasi fisik (PMTB) yang digunakan sebagai dasar penghitungan stok kapital serta penyempurnaan asumsi-asumsi yang digunakan. Sebagaimana telah disebutkan diatas, terdapat tiga asumsi penting yang perlu ditetapkan dalam perhitungan stok kapital dengan metode PIM, yaitu: asumsi umur aset (asset life), pola distribusi (discard pattern/survival function) dan metode depresiasi (depreciation method). Umur aset adalah jangka waktu sampai seberapa lama suatu aset 
dapat digunakan, sedangkan pola distribusi adalah suatu pola yang menggambarkan hilangnya nilai tertentu dari suatu populasi aset. Sementara itu, metode depresiasi adalah metode yang digunakan untuk menghitung seberapa besar nilai aset disusutkan dari waktu ke waktu.

Asumsi umur aset dapat ditentukan melalui survei-survei khusus sehingga asumsi yang digunakan relatif lebih realistis, namun penyelenggaraan survei-survei tersebut tentunya memakan biaya yang tidak sedikit dan waktu yang relatif lama. Untuk itu, langkah yang ditempuh biasanya adalah melakukan studi literatur mengenai penggunaan asumsi umur aset di negara-negara lain (best practices) ataupun dengan cara menggali informasi dari orangorang yang berpengalaman pada bidang-bidang tertentu (expert opinion). Seperti halnya asumsi umur aset, asumsi pola distribusi idealnya juga ditentukan melalui survei-survei khusus. Secara teoritis, setidaknya terdapat 6 jenis pola distribusi yang sering digunakan, yaitu: pola standard, linear dan delayed linear serta pola Logistic, Weibull, dan Winfrey. Dalam penelitian ini, dilakukan simulasi perhitungan stok kapital dengan menggunakan asumsi-asumsi tersebut, kecuali pola Winfrey karena masih belum lengkap informasi yang diperoleh. Sementara itu, untuk metode depresiasi digunakan metode straight line sebagaimana banyak digunakan oleh negara-negara maju, seperti Belanda dan Australia.

\section{PENDEKATAN TEORITIS STOK KAPITAL}

Secara teoritis, perekonomian suatu negara ditentukan oleh setidaknya dua faktor produksi, yaitu barang modal (capital) dan tenaga kerja (labor). Barang modal atau kapital memberikan kontribusi berupa bangunan, mesin-mesin, alat transportasi dan barang modal lainnya, sedangkan kontribusi tenaga kerja diwujudkan dalam bentuk keahlian (skill). Kedua faktor produksi tersebut secara bersama-sama menggerakkan variabel-variabel ekonomi lainnya sehingga terjadi pertumbuhan ekonomi.

Studi empiris menunjukkan bahwa kapital merupakan faktor produksi yang dominan dalam mendorong pertumbuhan ekonomi. Faktor produksi kapital diperoleh karena adanya kegiatan investasi, dimana sebagian dari investasi tersebut dibelanjakan untuk membeli berbagai barang modal yang akan digunakan dalam suatu proses produksi. Peran dari barang modal tersebut adalah mentransformasikan berbagai input menjadi output atau produk. Dengan kata lain, investasi merupakan salah satu bagian penting dalam suatu perekonomian karena investasi mempunyai keterkaitan dengan berlangsungnya kegiatan ekonomi pada masa sekarang maupun pada masa yang akan datang.

Tujuan dilakukannya penghitungan stok kapital dalam penelitian ini adalah: (1) untuk memperoleh gambaran mengenai produk neto (nilai tambah neto) dari hasil suatu proses 
produksi, yaitu seluruh nilai produksi dikurangi dengan besarnya penyusutan (consumption of fixed capital), (2) sebagai gambaran nilai kekayaan (wealth capital stock) yang diperoleh dari hasil pembangunan dalam suatu periode tertentu, (3) dapat dimanfaatkan untuk mengetahui produktifitas dan efisiensi suatu perokonomian (economic efficiency dan economic productivity). Tujuan dalam penelitian ini lebih diarahkan pada penghitungan stok kapiiłalldalam konsep 'wealth' karena untuk mengetahui economic produktivity diperlukan penelitian lebih lanjut untuk memperoleh data/informasi mengenai besaran productive capital stock.

\section{Konsep dan Definisi Stok Kapital}

Secara umum, konsep mengenai kapital dapat dilihat dari dua pendekatan yaitu konsep arus (flows) dan konsep stok (stock). Arus menujukkan "perubahan" (pertambahan atau pengurangan), sedangkan "stok" lebih menunjukkan posisi (nilai pada saat tertentu). Dalam terminologi lain, adanya proses perubahan tersebut dikenal sebagai suatu proses akumulasi. Dengan demikian, data stok kapital yang merupakan tujuan dalam penelitian ini menggambarkan posisi barang modal yang terbentuk dari suatu proses akumulasi dalam jangka waktu tertentu (umumnya relatif panjang). Kedua konsep 'arus' dan 'stok' tersebut masing-masing memiliki makna yang berbeda namun saling mendukung sesuai dengan prinsip pencatatan transaksinya. Untuk lebih jelasnya, berikut ini beberapa definisi yang berkaitan dengan stok kapital:

\section{INVESTASI}

Investasi adalah suatu kegiatan penanaman modal pada berbagai kegiatan ekonomi dengan harapan untuk memperoleh keuntungan (benefit) pada masa-masa yang akan datang. Investasi dibedakan menjadi dua, yaitu "investasi finansial" dan "investasi non-finansial". Yang dimaksud dengan investasi finansial adalah investasi dalam bentuk pemilikan instrumen finansial seperti penyertaan, pemilikan saham, obligasi dan sejenisnya, sedangkan investasi non-finansial adalah investasi dalam bentuk fisik (fixed capital), termasuk persediaan (inventory).

\section{PEMBENTUKAN MODAL TETAP BRUTO(PMTB)}

Pembentukan modal tetap bruto (PMTB) merupakan terminologi lain dari kapital yang digunakan dalam SNA 1968. Secara konsepsi, PMTB (gross fixed capital formation/GFCF) sebenarnya identik dengan besarnya investasi fisik yang direalisasikan di suatu negara/ wilayah pada suatu waktu tertentu (physical domestic investment). Disebut sebagai pembentukan modal tetap bruto karena tidak termasuk inventori (PMTB minus inventori). Apabila inventori dimasukkan sebagai bagian dari PMTB maka berubah menjadi pembentukan modal bruto (Gross Capital Formation). Dalam penelitian ini lebih 
difokuskan pada komponen data matriks PMTB yang merupakan bahan dasar dalam penyusunan data stok kapital.

PMTB didefinisikan sebagai pengadaan, pembuatan dan pembelian barang modal (capital goods) untuk keperluan usaha. Termasuk dalam kategori ini adalah peralatan yang akan digunakan dalam proses produksi secara terus menerus (repeatedly) dan berkesinambungan (continuously). Barang modal yang mempunyai usia pakai lebih dari satu tahun akan mengalami penyusutan baik secara teknis (usia pakai) maupun ekonomi (nilai).

Disebut sebagai pembentukan modal tetap bruto karena menggambarkan proses penambahan atau pengurangan barang modal padea suatu periode tertentu. Istilah bruto mengindikasikan bahwa didalamnya masih termasuk unsur penyusutan. Penyusutan ini menggambarkan besaran ausnya nilai barang modal sebagai akibat dari suatu proses produksi, yang pada sektor produksi dikompensasikan sebagai pengeluaran produksi (biaya primer).

\section{STOKKAPITAL}

Stok kapital didefinisikan sebagai persediaan berbagai jenis barang modal yang berujud (phisik), seperti bangunan, mesin-mesin dan perlengkapannya, alat transportasi, ternak dan barang modal lainnya, yang memberikan kontribusi terhadap kelangsungan suatu proses produksi. Barang modal tersebut harus dibuat oleh manusia dari berbagai sumber yang tersedia dan memiliki usia pakai yang relatif panjang (lebih dari 1 tahun). Namun konsep ini tidak berlaku bagi barang modal yang nilainya relatif murah meskipun usia pakainya lebih dari satu tahun, seperti alat tulis, kalkulator, peralatan makan, cangkul, sabit dan sejenisnya. Barang-barang tersebut dianggap sebagai barang antara (intermediate goods) dalam suatu proses produksi.

\section{Batasan Stok Kapital}

Dalam pengertian sesungguhnya, barang modal lebih menekankan pada aspek "riil" daripada moneter. Untuk memperjelas dan memberi gambaran yang lebih konkrit mengenai jenis-jenis aset yang dapat dikategorikan sebagai barang modal maka perlu adanya batasanbatasan kriteria barang modal. Adapun batasan stok kapital secara lebih rinci adalah sebagai berikut:

a. Dibuat oleh manusia dan merupakan salah satu faktor dalam proses produksi dalam bentuk barang modal atau peralatan. Barang yang dibuat untuk tujuan konsumsi tidak termasuk dalam kategori stok kapital. 
b. Memiliki usia pakai lebih dari 1 tahun (durable goods) dan nilainya relatif mahal.

c. Digunakan dalam proses produksi pembuatan barang dan jasa secara terus menerus (repeatedly) dan berkesinambungan (continuously), baik secara langsung maupun tidak langsung.

d. Mencakup pembelian dan pengadaan barang modal baru dari dalam negeri, serta barang modal baru maupun bekas dari luar negeri.

e. Perbaikan secara besar-besaran yang tujuannya untuk meningkatkan produktivitas atau memperpanjang umur pemakaian barang-barang modal tersebut.

f. Pengeluaran untuk peningkatan nilai guna tanah, seperti: kegiatan pengembangan dan pembukaan lahan baru, pematangan tanah dan reklamasi, perluasan hutan, perluasan perkebunan, dan sejenisnya.

Sementara itu yang tidak digolongan sebagai barang modal adalah:

a. Pembelian tanah

b. Pengeluaran pemerintah untuk keperluan pertahanan dan keamanan (militer)

c. Pembelian barang tahan lama oleh rumah tangga yang bukan untuk keperluan usaha

d. Pengadaan ternak untuk tujuan dipotong/dikonsumsi (bukan untuk dikembangbiakkan)

e. Barang modal tidak berwujud (intangible assets) seperti hak paten, hak cipta dan hak kepemilikan (property) sejenis.

Berkaitan dengan penyusunan data stok kapital, secara definitif yang dimaksud dengan stok kapital adalah posisi nilai barang modal (capital goods) pada satu saat tertentu yang terjadi akibat dari adanya suatu proses akumulasi, yang kemudian digunakam dalam proses produksi secara terus menerus (repeatedly) dan berkesinambungan (continuously). Data stok kapital ini akan disajikan dalam format time series dan matriks dari tahun 1980 sampai dengan 2000 (estimasi), berbasis pada data PMTB serial data PDB.

\section{Jenis-jenis Barang Modal}

Ada beberapa cara yang dapat dilakukan untuk melakukan penggolongan barang modal, seperti klasifikasi PMTB dalam PDB, klasifikasi barang modal dalam Tabel I-O ataupun klasifikasi barang modal yang digunakan di negara-negara lain. Dalam penelitian ini penggolongan jenis barang modal dilakukan atas dasar klasifikasi menurut Tabel I-O dengan pertimbangan kepraktisan dan fleksibilitasnya. Adapun jenis-jenis barang modal tersebut adalah sebagai berikut: 


\section{BANGUNAN / KONSTRUKSI}

Mencakup pengeluaran untuk pembentukan modal tetap dalam bentuk bangunan atau konstruksi yang terdiri atas:

a. bangunan tempat tinggal (residential buildings): mencakup bangunan rumah untuk tujuan sebagai tempat tinggal, baik jadi maupun setengah jadi.

b. bangunan bukan tempat tinggal (non-residential buildings): mencakup bangunan bukan untuk sebagai bukan tempat tinggal seperti bangunan kantor, bangunan pabrik dan sebagainya, baik jadi maupun setengah jadi.

c. bangunan atau konstruksi lainnya diantaranya seperti: jalan, jembatan, irigasi, pembangkit tenaga listrik dan jaringannya, instalasi telekomunikasi, pemancar televisi, terminal dan pelabuhan, serta jaringan pipa untuk minyak, gas, dan air, baik jadi maupun setengah jadi.

d. Perbaikan secara besar-besaran untuk bangunan tersebut.

\section{MESIN-MESIN}

Mencakup pengeluaran untuk pengadaan mesin-mesin dan perlengkapannya, diantaranya untuk kegiatan pertanian, pertambangan dan penggalian, industri pengolahan, pembangkit listrik, pembuat jalan, jembatan, perlengkapan kantor, hotel, restoran, toko, pelabuhan, bangunan sekolah, dan rumah sakit.

\section{ALAT-ALATTRANSPORTASI}

Mencakup pengeluaran untuk pengadaan alat-alat atau sarana angkutan seperti: kereta api, kapal laut, pesawat udara, mobil angkutan penumpang bermotor, mobil angkutan barang bermotor, mobil angkutan penumpang tidak bermotor, mobil angkutan barang tidak bermotor, perahu penyeberangan dan sejenisnya.

\section{TERNAK}

Mencakup pengeluaran untuk pembelian ternak, pembibitan dan pemeliharaan ternak dengan tujuan untuk diambil hasil-hasilnya, termasuk pula yang dipakai tenaganya, diantaranya seperti: sapi, kuda, kerbau, domba, kambing, ayam, bebek, dan sejenisnya.

\section{PERLENGKAPAN}

Mencakup pengeluaran untuk peralatan listrik, peralatan yang terbuat dari logam, dan peralatan serta perlengkapan yang terbuat dari kain dan kulit, seperti: karpet, kantongkantong penyimpan, dan furnitur. 


\section{BARANG MODAL LAINNYA}

Mencakup pengadaan barang-barang elektronik, barang-barang komunikasi termasuk perlengkapannya, alat ukur, alat fotografi, alat optik, jam, alat musik, alat olah raga, perabot rumah tangga terbuat dari bambu dan rotan, barang terbuat dari kaca, barang terbuat dari keramik, dan barang dari bahan bukan logam.

\section{Klasifikasi Barang Modal}

Secara umum pengklasifikasian stok kapital atau barang modal dibedakan menurut 4 (empat) penggolongan utama, yaitu:

1. Menurut jenis-jenis barang modal

2. Menurut lapangan usaha atau sektor ekonomi produksi

3. Menurut institusi/kelembagaan atau pelaku ekonomi

4. Menurut wilayah asal atau sumber penyediaan barang modal.

Selanjutnya, matriks yang akan dibentuk merupakan kombinasi klasifikasi kapital menurut jenis barang modal dengan klasifikasi kapital lainnya (yaitu kapital menurut sektor lapangan usaha, kapital menurut institusi dan kapital menurut sumber/asal). Terdapat dua sumber data yang dapat digunakan dalam menyusun matriks stok kapital, yaitu serial data PDB dan serial tabel Input-Output (I-O). Data stok kapital dalam tabel I-O mempunyai tingkat kerincian yang relatif lebih baik dibandingkan dengan kerincian yang ada dalam PDB.

Meskipun keduanya membahas hal yang sama, tetapi besaran-besaran nilai (level) yang disajikan relatif berbeda, namun secara total perbedaan tersebut tidak terlalu signifikan. Dalam kaitannya dengan penyusunan matriks stok kapital disini, maka level yang akan dijadikan sebagai basis data penyusunan matriks stok kapital adalah data dalam serial PDB. Sementara itu, rincian jenis barang modal yang digunakan adalah data stok kapital yang bersumber dari serial tabel I-O.

Langkah yang dilakukan untuk menyusun klasifikasi barang modal adalah dengan menyusun ulang klasifikasi (reklasifikasi) jenis barang modal. Reklasifikasi ini dilakukan karena adanya perbedaan yang cukup mendasar antara kedua sumber tersebut diatas. Penggolongan jenis barang modal menurut klasifikasi PMTB dalam PDB jauh lebih sederhana (4 jenis barang modal) dibandingkan dengan klasifikasi dalam tabel I-O (34 komoditi). Hasil reklasifikasi yang merupakan modifikasi dari kedua sumber tersebut dapat dilihat pada appendix. 


\section{Prinsip Pencatatan dan Dasar Penilaian Stok Kapital PRINSIP PENCATATAN BARANG MODAL}

\section{Konsep arus (flows) dan stok (stocks)}

Yaitu sistem pencatatan yang menggambarkan perubahan barang modal dalam suatu periode waktu tertentu (mutasi). Sedangkan stok merupakan sistem pencatatan yang menggambarkan posisi barang modal pada suatu periode tertentu. Pada akhirnya stok terbentuk karena adanya perubahan yang terjadi dari proses arus (akumulasi).

\section{Sistem pencatatan dua kali (double entry system)}

Merupakan tata cara pencatatan barang modal yang dapat dilakukan melalui 2 (dua) pendekatan, yaitu dari sisi yang menggunakan (user), dan/atau dari sisi yang menghasilkan (producer). Sistem pencatatan ini menunjukkan adanya konsistensi dan keseimbangan dalam setiap pencatatan transaksi barang modal. Sebagai contoh: lokomotif, disatu sisi dicatat sebagai produk yang dihasilkan oleh sektor industri manufaktur (producer), sementara disisi lain akan dicatat sebagai barang modal yang dikuasai oleh industri jasa pengangkutan (user).

\section{Waktu pencatatan}

Barang modal akan dicatat sebagai dikuasai atau dimiliki oleh pihak pengguna apabila sudah terjadi perpindahan dan secara hukum sudah sah untuk dimiliki. Barang modal yang sudah diproduksi tetapi belum dipasarkan (stok pada produsen), belum dicatat sebagai bagian dari pembentukan modal.

Dalam kaitannya dengan penyusunan data stok kapital disini maka ketiga konsep pencatatan tersebut digunakan secara bersama-sama. Konsep arus (proses akumulasi) digunakan pada saat penyusunan matrik Pembentukan Modal Tetap Bruto (PMTB), sedangkan konsep stok akan digunakan pada waktu penyusunan matrik stok kapital. Sementara itu sistem pencatatan dua kali hanya akan nampak pada transaksi-transaksi tertentu, terutama apabila transaksi pada dua neraca yang terkait dapat disajikan secara bersama-sama.

\section{DASAR PENILAIAN BARANG MODAL}

\section{Basis akrual (accrual basis) dan basis tunai/kas (cash basis)}

Penilaian barang modal didasarkan pada konsep basis akrual atau penilaian berdasarkan aliran transaksi barang modal secara riil (real flows). Penilaian berdasarkan basis akrual adalah pencatatan nilai barang modal pada saat nilai ekonomisnya terjadi tanpa melihat perubahan kepemilikan. Sedangkan pencatatan berdasarkan basis kas 
adalah pencatatan nilai barang modal berdasarkan aliran uang tunai (cash flows) yaitu ketika uang berpindah tangan dari pihak pembeli ke pihak penjual. Tata cara pencatatan transaksi barang modal disini menggunakan basis akrual sesuai dengan konsep yang direkomendasi oleh Sistem Neraca Nasional / System of National Accounts (SNA).

\section{Nilai transaksi atas dasar harga pembeli}

Stok kapital dinilai atas dasar harga pembelian yang berlaku, yang menggambarkan nilai yang dibayar pengguna pada waktu membeli barang modal tersebut. Selain itu, nilai stok kapital dicatat atas dasar nilai buku (book value), yaitu nilai pembelian barang modal pada harga pasar dikurangi dengan nilai akumulasi penyusutannya. Nilai buku tersebut menunjukkan kemampuan stok kapital untuk digunakan dalam proses ekonomi yang sedang berjalan maupun yang akan datang.

\section{Nilai transaksi atas dasar harga berlaku dan atas dasar harga konstan}

Penilaian kapital atas dasar harga berlaku (current year) merupakan penilaian volume barang modal sesuai dengan harga yang terjadi pada tahun berjalan. Sedangkan penilaian stok kapital atas dasar harga konstan (constant year) merupakan penilaian volume barang modal sesuai dengan harga pada tahun dasar, yang telah ditentukan sebelumnya. Penentuan tahun dasar ini biasanya dipilih tahun yang mencerminkan keadaan ekonomi dalam kondisi normal. Perkiraan atas dasar harga konstan dilakukan dengan cara membagi nilai harga berlaku dengan indeks harga yang sesuai (metode deflasi).

\section{PROSEDUR PENGHITUNGAN STOK KAPITAL DENGAN METODE PIM}

Stok kapital merupakan akumulasi investasi dalam suatu periode tertentu. Oleh karenanya, terdapat beberapa prinsip penting yang digunakan dalam penghitungan stok kapital, yaitu pengubahan data arus (flows) yang berupa investasi per tahun menjadi data stok (stocks) berupa stok kapital. Proses perubahan data arus menjadi data stok tersebut dilakukan dengan menggunakan beberapa asumsi, yaitu umur aset, pola distribusi umur aset dan metode depresiasi dari suatu jenis aset.

\section{Penentuan Probabilitas dan Distribusi dari Fungsi Kepekatan Umur}

Penghitungan stok kapital dalam penelitian ini menggunakan 5 jenis pola distribusi umur aset, yaitu pola distribusi Standard (Std), Linear (L), Delayed Linear (DL), Logistic (Log) 
dan Weibull (W). Untuk setiap jenis pola distribusi, stok kapital akan dihitung dengan menggunakan metode Australia dan metode Belanda.

Pada suatu jenis distribusi yang bersifat kontinyu, terdapat apa yang disebut dengan Probability Density Function (PDF) atau yang disebut dengan $f(x)$. Secara umum, $f(x)$ merupakan intensitas atau kerapatan dari nilai-nilai dari suatu variabel acak pada suatu gugus pemetaan dari variabel acak tersebut. Untuk suatu fungsi yang kontinyu maka besarnya peluang di satu titik adalah nol. Oleh karena itu, maka besarnya suatu probabilitas harus ditentukan dalam suatu rentang tertentu yang dalam penelitian mengenai stok kapital ini dinyatakan dengan umur suatu aset.

Untuk menghitung probabilitas dalam suatu rentang tertentu harus digunakan fungsi kumulatif densitas probabilitas atau Cummulative Density Function (CDF) yang biasa disingkat dengan $F$. Dalam hal stok kapital, CDF dipergunakan untuk mengestimasi besarnya kemungkinan suatu aset tidak berfungsi (discard) sebelum mencapai batas umur atau usia pakainya.

Untuk kepentingan pendugaan besarnya CDF, yang harus ditentukan pertama kali adalah bentuk sebaran CDF sesuai dengan bentuk sebaran yang diinginkan. Untuk mempermudah pembagian berdasarkan umur dan menjaga cukup presisinya angka penghitungan yang digunakan, maka sebagai dasar sebaran digunakan nilai $x$ dari 0 sampai dengan $100(x \in[0,100])$. Selanjutnya, PDF dari rentang $\mathrm{x}$ tertentu adalah:

$$
P D F\left(x_{t}\right)=F\left(x_{t}\right)-F\left(x_{t-1}\right)
$$

Sebagai contoh untuk suatu aset yang punya rentang umur 20 tahun, maka untuk setiap tahunnya dipergunakan rentang $x=5$ untuk setiap tahun umurnya. Dengan demikian, untuk aset yang telah berumur 10 tahun dipergunakan CDF dengan $x=50$, untuk yang telah berumur 11 tahun dipergunakan CDF dengan $x=55$, dan seterusnya.

Berkebalikan dari pola tidak berfungsinya suatu aset adalah pola probabilitas masih berfungsinya suatu aset (survival function) atau $S(x)$, dengan formulasi:

$$
S(x)=1-F(x)
$$

Apabila dikaitkan dengan pendekatan penghitungan stok kapital, pendekatan CDF dipakai dalam penghitungan stok kapital dengan metode Australia sedangkan pendekatan Survival Function dipakai dalam penghitungan stok kapital dengan metode Belanda. 
Beberapa pola distribusi dan parameter yang digunakan, serta regresi yang dilakukan pada tahap awal penghitungan stok kapital adalah sebagai berikut:

\section{POLA DISTRIBUSISTANDARD}

Pola ini merupakan pola distribusi paling sederhana dibandingkan pola distribusi lainnya. Sebaran survival pola distribusi ini memiliki makna bahwa suatu jenis aset akan secara serentak tidak berfungsi pada saat aset tersebut mencapai umur yang diharapkan. Sebagai contoh, apabila pada permulaan terdapat 100 barang dari suatu jenis aset yang berumur 10 tahun, maka selama aset tersebut belum mencapai umur 10 tahun, maka seluruh 100 barang tersebut masih terus berfungsi. Pada saat umur aset mencapai 10 tahun, secara serentak seluruh 100 barang tersebut tidak berfungsi lagi. Secara matematis, pola distribusi standard dapat diformulasikan:

$$
f(x)=\left\{\begin{aligned}
0 & \text { untuk } 0 \leq x \leq \text { umur } \\
1 & \text { untuk } x=\text { umur }
\end{aligned}\right.
$$

Bentuk CDF nya juga sederhana, yaitu:

$$
F(x)=\left\{\begin{aligned}
0 & \text { untuk } 0 \leq x \leq \text { umur } \\
1 & \text { untuk } x=\text { umur }
\end{aligned}\right.
$$

Bentuk pola distribusi ini relatif mudah dan sederhana, baik dalam penghitungan maupun justifikasi yang diperlukan. Dalam terminologi lain, istilah pola distribusi standard ini identik dengan metode simultaneous exit yang digunakan oleh Singapore.

\section{POLA DISTRIBUSI LINEAR}

Pola distribusi linear ini mempunyai pola sebaran umum sebagai berikut:

$$
f(x)=\left\{\begin{array}{cl}
\frac{1}{b} & \text { untuk } 0 \leq x \leq b \\
0 & \text { untuk } x \text { lain }
\end{array}\right.
$$


$f(x)$ menyatakan fungsi Probability Density Function (PDF). Bentuk CDF nya adalah:

$$
F(x)=\left\{\begin{array}{ccl}
0 & \text { untuk } & x<0 \\
\frac{x}{b} & \text { untuk } & 0 \leq x \leq b \\
1 & \text { untuk } & x>b
\end{array}\right.
$$

Dalam penghitungan stok kapital ini, parameter $b$ ditentukan sebesar 100. Pola distribusi linear ini dapat diartikan bahwa secara konstan jumlah seluruh barang dari suatu jenis aset yang ada menjadi tidak berfungsi seiring dengan bertambahnya umur aset. Sebagai contoh, apabila ada 100 barang dari suatu jenis aset tertentu yang berumur 10 tahun, maka setiap tahunnya, terdapat 10 barang yang menjadi tidak berfungsi sebelum mencapai umurnya.

\section{POLA DISTRIBUSI DELAYED LINEAR}

Pada dasarnya, pola distribusi delayed linear hampir sama dengan pola distribusi linear. Perbedaannya terletak pada dimulainya suatu barang yang secara konstan menjadi tidak berfungsi sebelum umur waktunya. Sebagai ilustrasi, dapat dicontohkan bahwa dari jumlah 100 barang suatu jenis aset baru mulai tidak berfungsi pada tahun ke-3, ke-4 dan seterusnya. Perbedaannya dengan pola linear adalah bahwa terjadinya barang yang discard pada pola linear dimulai langsung sejak dari barang tersebut dibeli, sedangkan pada pola delayed linear baru dimulai misalnya pada tahun ke-3 dan seterusnya.

Fungsi PDF pola delayed linear $f(x)$ dapat diformulasikan sebagai berikut:

$$
f(x)=\left\{\begin{array}{cl}
\frac{1}{b-a} & \text { untuk } 0 \leq x \leq b \\
0 & \text { untuk x lain }
\end{array}\right.
$$

Bentuk CDF nya adalah:

$$
F(x)=\left\{\begin{array}{lll}
0 & \text { untuk } & x<a \\
\frac{x-a}{b-a} & \text { untuk } & a \leq x \leq b \\
1 & \text { untuk } & x>b
\end{array}\right.
$$


Dalam penelitian ini, nilai parameter yang digunakan dalam pola distribusi delayed linear adalah $a=10,68$ dan $b=100$. Penentuan nilai parameter tersebut diperoleh dengan menggunakan regresi melalui persamaan:

$$
F(x)=\frac{-a}{b-a}+\frac{1}{b-a} x
$$

\section{POLA DISTRIBUSI LOGISTIC}

Pola distribusi ini ditentukan oleh 2 parameter utama, yaitu $\mu$ dan $\beta$; dimana $\mu$ menyatakan parameter bentuk distribusinya sedangkan $\beta$ menyatakan parameter keragamannya.

Distribusi ini mempunyai Fungsi Probability Density Function $f(x)$ sebagai berikut:

$$
f(x)=\frac{1}{\beta} \frac{e^{-\frac{(x-\mu)}{\beta}}}{\left(1+e^{-\frac{(x-\mu)}{\beta}}\right)}
$$

Bentuk CDF nya adalah:

$$
F(x)=\frac{1}{\left(1+e^{-\frac{(x-\mu)}{\beta}}\right)}
$$

Nilai parameter yang digunakan adalah $\mu=58,80$ dan $\beta=9,35$.

Nilai parameter tersebut didapatkan melalui regresi berdasarkan persamaan:

$$
-\ln \left(\frac{1}{F(x)}-1\right)=\frac{-\mu}{\beta}+\frac{1}{\beta} x
$$

Pola distribusi logistic ini bermakna bahwa penurunan jumlah barang dari suatu jenis aset pada periode umur aset mengikuti bentuk kurva. Pada kurva logistic ini, penurunan jumlah aset pada tahun-tahun awal umur aset masih relatif sedikit, namun sejalan dengan bertambahnya umur, semakin banyak aset yang discard hingga mencapai suatu saat dimana 
selanjutnya jumlah aset yang discard terus bertambah namun dengan jumlah yang semakin berkurang, dan akhirnya pada saat umur aset tercapai, seluruh aset sudah tidak berfungsi lagi. Karakteristik umum dari pola distribusi ini adalah bahwa pada saat aset mencapai setengah dari umurnya, maka jumlah aset yang masih hidup (survive) juga setengah dari jumlah awalnya.

\section{POLA DISTRIBUSI WEIBULL}

Pola distribusi ini mempunyai 2 parameter utama yaitu $\alpha$ dan $\lambda$; dimana $\alpha$ menyatakan parameter bentuk distribusinya, sedangkan $\lambda$ menyatakan parameter keragamannya.

Distribusi ini mempunyai fungsi PDF $f(x)$ sebagai berikut:

$$
f(x)=\alpha \lambda(\alpha \lambda)^{\alpha-1} \cdot e^{(\lambda x)^{\alpha}} ; \quad x>0 ; \alpha>0 ; \lambda>0
$$

Bentuk CDF-nya adalah:

$$
F(x)=1-e^{-(\lambda x)^{\alpha}}
$$

Dalam beberapa buku textbook, terminologi $\lambda$ dapat digantikan menggunakan $\beta$ yang pada prinsipnya sama, dimana antara $\lambda$ dan $\beta$ terdapat hubungan sebagai berikut:. $\beta=\frac{1}{\lambda}$

Dalam penelitian ini nilai parameter yang digunakan adalah $\alpha=2.74$ dan $\lambda=0.016$ (atau $\beta$ =65.37) yang diperoleh melalui persamaan regresi:

$$
\ln (-\ln [1-F(x)])=\alpha \ln (\lambda)+\alpha \ln (x)
$$

Pola distribusi Weibull ini mempunyai makna yang menyerupai pola distribusi logistic, hanya saja bentuk kurvanya yang berbeda dan tidak diasumsikan bahwa pada saat suatu aset mencapai setengah umurnya, maka jumlah aset yang masih survive juga setengahnya.

\section{Transformasi Data PMTB menjadi Gross Capital Stock (GCS)}

Pada dasarnya transformasi data matriks PMTB menjadi Gross Capital Stock (GCS) merupakan penjumlahan semua data investasi yang terjadi dalam suatu periode dikurangi 
dengan jumlah aset yang tidak berfungsi. Asumsi awal yang dipakai adalah bahwa sebelum periode tersebut tidak ada kegiatan investasi. Meskipun asumsi ini tidak realistis, namun dapat digunakan pada tahap awal untuk mengetahui angka stok kapital yang belum disesuaikan. Angka stok kapital yang belum disesuaikan ini kemudian akan digelembungkan (gross-up) dengan memperhitungkan angka investasi sebelum periode penghitungan.

Metode penggelembungan ini ada beberapa cara antara lain: estimasi stok kapital periode sebelumnya, regresi liniear trend stok kapital dan gabungan kedua cara tersebut. Metode yang dilakukan saat ini, adalah metode yang paling sederhana yaitu melakukan regresi linear stok kapital yang didapat dan mencocokkannya dengan data investasi yang tersedia sebelum periode penghitungan sebagai dasar mengestimasi angka penggelembungan stok kapital pada awal periode. Penghitungan teknis penggelembungan tersebut akan diuraikan pada bab selanjutnya.

Pola retirement ditentukan dari CDF sesuai dengan pola distribusi yang digunakan. Apabila $f(x)$ ini menyatakan fungsi CDF maka besar retirement yang terjadi untuk investasi pada tahun tertentu, dinyatakan dengan :

$$
R_{t}(I)=f\left(x_{t}\right) . I_{1} \quad t=0,1,2, \ldots m \quad \text { dimana } m \text { adalah umur suatu jenis aset }
$$

Hal yang sama dilakukan untuk investasi yang terjadi pada tahun berikutnya dan seterusnya.

Besar retirement pada suatu tahun tertentu misalnya tahun ke-i dapat diketahui, yaitu:

$$
\operatorname{ret}_{i}=\sum_{t=0}^{i-1} R_{t}\left(I_{i-t}\right)
$$

Gross Capital Stock (GCS) dihitung dengan:

$$
G C S_{i}=I_{i}-r e t_{i}+G C S_{i-1} \text { dimana } \quad G C S_{0}=0
$$

Hubungan antara besarnya investasi dalam suatu periode ( 1 s.d n) dengan besarnya GCS pada akhir periode adalah:

$$
\sum_{i=1}^{n} I=G C S_{n}+\sum_{i=1}^{n} r e t
$$

Penghitungan dengan menggunakan CDF ini digunakan dalam penghitungan stok kapital metode Australia, sedangkan untuk penghitungan dengan menggunakan Survival Function digunakan dalam metode Belanda. Pada dasarnya penghitungan dengan menggunakan Survival Function akan menghasilkan angka yang sama. Perbedaan antara kedua metode tersebut terletak pada cara melihat fungsi distribusi suatu aset. 


\section{Transformasi Data PMTB menjadi Net Capital Stock (NCS) METODE PERHITUNGAN AUSTRALIA}

Berdasarkan data PDF yang diperoleh pada setiap umur CDF-nya, maka dapat disusun suatu besaran $Q$ yang menjelaskan jumlah populasi aset yang ter-discard atau menjadi rusak sekaligus terdepresiasi dari jumlah semulanya. Untuk suatu tahun tertentu, besaran tersebut dinyatakan sebagai:

$$
q_{t}=P D F_{t} . D e p r_{t}
$$

dimana nilai depresiasinya adalah:

$$
D e p r_{t}=\frac{1}{n+1-t}
$$

dengan demikian, total depresiasi yang masih dihitung untuk umur tertentu (Qi) adalah:

$$
Q_{i}=\sum_{t-i}^{n} q_{t}
$$

Selanjutnya, dengan menggunakan matriks bantu $\mathrm{M}$, maka besaran depresiasi yang terjadi (D) dapat dihitung dengan menggunakan data investasi menjadi:

$$
\left[\begin{array}{c}
D_{1} \\
D_{2} \\
\ldots \\
D_{n}
\end{array}\right]=\left[\begin{array}{cccc}
M_{11} & M_{12} & \ldots & M_{1 n} \\
M_{21} & M_{22} & \ldots & \ldots \\
\ldots & \ldots & \ldots & \ldots \\
M_{k 1} & \ldots & \ldots & M_{k n}
\end{array}\right] \cdot\left[\begin{array}{c}
Q_{1} \\
Q_{2} \\
\ldots \\
Q_{n}
\end{array}\right]
$$

Matriks bantu M yang sesungguhnya adalah matriks berisikan data investasi yang disusun sedemikian rupa berbentuk:

$$
M=\left[\begin{array}{cccc}
I_{1} & 0 & \ldots & 0 \\
I_{2} & I_{1} & 0 & 0 \\
\ldots & \ldots & \ldots & \ldots \\
I_{k} & I_{k-1} & \ldots & I_{1}
\end{array}\right]
$$

Selanjutnya perlu dihitung angka depresiasi yang telah disesuaikan (AdjD) dengan menggunakan formula:

$$
\operatorname{Adj} D_{i}=\frac{1}{2}\left(D_{i-1}+D_{i}\right)
$$


Setelah mendapatkan angka depresiasi yang telah disesuaikan, maka N et Capital Stock (NCS) dapat dihitung:

$$
N C S_{i}=N C S_{i-1}+I_{i}-A d j D_{i} \text { dimana } \quad N C S_{0}=0
$$

Dengan demikian, pada tahun pertama angka GCS akan sama dengan NCS.

\section{METODE PERHITUNGAN BELANDA}

Berbeda dengan metodeA ustralia yang menggunakan pendekatan D iscard Function, metode penghitungan stok kapital Belanda menggunakan pendekatan probabilitas suatu aset akan survive( $P D F^{\text {survive }}$ ) yang diperoleh dari selisih Survival Function-nya, yaitu:

$$
P D F_{t}^{\text {survive }}=S_{t-1}-S_{t}
$$

Variabel bantu $q^{\prime}$ yang merupakan perkalian antara dengan sisa umurnya, dirumuskan:

$$
q^{\prime}{ }_{t}=P D F_{t}^{\text {survive }} .(n+1-t) \quad ; \quad t=1,2, \ldots, n
$$

Selanjutnya, variabel Q' yang merupakan matriks bantu untuk menghitung angka depresiasi diperoleh dengan menambahkan angka Survival $\left(S_{t}\right)$ dengan variabel bantu $q^{\prime}$ dan dirumuskan menjadi:

$$
Q_{t}^{\prime}=S_{t}+q_{t}^{\prime}
$$

Dengan menggunakan matriks bantu M' dan Q', besarnya depresiasi (D) dapat dihitung dengan menggunakan formula:

$$
\left[\begin{array}{c}
D_{1} \\
D_{2} \\
\ldots \\
D_{n^{\prime}}
\end{array}\right]=\left[\begin{array}{cccc}
M^{\prime}{ }_{11} & M_{12}^{\prime} & \ldots & M^{\prime}{ }^{\prime}{ }^{\prime} \\
M^{\prime}{ }_{21} & M^{\prime}{ }_{22} & \ldots & \ldots \\
\ldots & \ldots & \ldots & \ldots \\
M^{\prime}{ }_{j 1} & \ldots & \ldots & M^{\prime}{ }_{j n^{\prime}}^{\prime}
\end{array}\right] \cdot\left[\begin{array}{c}
Q_{1}^{\prime} \\
Q_{2}^{\prime} \\
\ldots \\
Q_{n^{\prime}}^{\prime}
\end{array}\right]
$$

Matriks bantu M' pada metode Belanda pada dasarnya hampir sama dengan matriks bantu M pada metode Australia. Perbedaan antara $M$ dengan $M$ ' terletak pada cara menyusun matriks investasinya sebagai berikut: 


$$
M^{\prime}=\left[\begin{array}{cccc}
I_{1} & 0 & \ldots & 0 \\
I_{2} & I_{1} & \ldots & 0 \\
I_{3} & I_{2} & \ldots & \ldots \\
\ldots & \ldots & \ldots & I_{1} \\
I_{j 1} & \ldots & I_{3} & I_{2}
\end{array}\right]
$$

Selanjutnya, adjusted depreciation-nya dihitung dengan menggunakan persamaan:

$$
\operatorname{Adj} D_{i}=\frac{1}{2 n^{\prime}}\left(D_{i-1}+D_{i}\right)
$$

Pada step terakhir, dapat dihitung net capital stock (NCS) metode Belanda dan metode Australia dengan menggunakan formula:

$$
N C S_{i}=N C S_{i-1}+I_{i}-\operatorname{Adj}_{i} \quad \text { dimana } \quad N C S_{0}=0
$$

\section{Penghitungan Stok Kapital pada Tahun Awal (Gross-up)}

Sebagaimana disebutkan pada awal pembahasan, bahwa untuk mengetahui nilai level stok kapital sehingga mendekati angka yang sebenarnya perlu dilakukan penggelembungan (gross-up) terhadap hasil penghitungan stok kapital. Disamping itu, prosedur penggelembungan ini dilakukan dengan tujuan untuk memperbaiki asumsi tahun awal bahwa stok kapital dari 1980 menjadi 1960. Secara teoritis, semakin mundur asumsi tahun awal stok kapital, data stok kapital yang diperoleh dalam angka level akan semakin baik. Hal ini didasarkan pada fakta bahwa stok kapital yang ada sekarang merupakan akumulasi investasi yang telah dilakukan sejak lama. Oleh karena itu, pada waktunya nanti asumsi tahun awal stok kapital ini akan terus diperbaiki, baik dari segi data investasi yang digunakan maupun metode adjustment yang digunakan.

Metode gross-up yang digunakan saat ini cukup sederhana, yaitu dengan cara melakukan linearisasi data PMTB tahun 1960 terhadap trend data stok kapital periode 19802000 yang telah ada (hasil perhitungan). 


\section{HASIL PERHITUNGAN STOK KAPITAL}

Pada bagian ini akan diuraikan hasil perhitungan stok kapital yang dilakukan dengan menggunakan data PMTB periode tahun 1980-2000. Stok kapital dihitung atas dasar akumulasi PMTB (investasi fisik) dengan mempertimbangan jumlah aset yang terdiscard dan nilai aset yang terdepresiasi, sementara untuk menentukan nilai discard dan depresiasinya tergantung pada asumsi-asumsi yang digunakan.

\section{Penetapan Asumsi}

Penghitungan stok kapital dengan metode PIM dilakukan dengan terlebih dulu menetapkan asumsi-asumsi yang digunakan. Untuk umur aset, asumsi yang digunakan adalah best practices di negara-negara lain yang telah mengimplementasikan metode PIM. Untuk menyederhanakan proses penghitungan stok kapital, digunakan asumsi umur aset bahwa suatu jenis barang modal memiliki umur aset yang sama meskipun dimiliki oleh sektor ekonomi ataupun institusi yang berbeda. Adapun asumsi umur aset yang digunakan dalam penghitungan stok kapital ini adalah:

\begin{tabular}{|l|l|c|}
\hline No. & Jenis Barang Modal & Umur (tahun) \\
\hline 1. & Bangunan & 20 \\
2. & Mesin I & 16 \\
3. & Mesin II & 18 \\
4. & Transportasi & 10 \\
5. & Ternak & 3 \\
6. & Perlengkapan - Listrik & 10 \\
7. & Perlengkapan - Logam & 5 \\
8. & Perlengkapan - Kain \& Kulit & 5 \\
9. & Lainnya & 16 \\
\hline \multicolumn{2}{l|}{ Keterangan: } \\
Mesin I: & Mesin penggerak mula, mesin dan perlengkapannya, \\
\multicolumn{2}{|l|}{ Mesin II: } & Mesin listrik dan perlengkapannya \\
\hline
\end{tabular}

Selain itu, diasumsikan pula bahwa masing-masing pola distribusi (Standard, Linear, Delayed Linear, Logistic, dan Weibull) mengikuti asumsi pola survival yang sama yaitu: 


\begin{tabular}{|c|c|}
\hline Rentang Umur Aset & Sisa Populasi (Survival) \\
\hline s.d. $25 \%$ & $90 \%$ \\
s.d. $50 \%$ & $70 \%$ \\
s.d. $75 \%$ & $40 \%$ \\
s.d. $90 \%$ & $10 \%$ \\
s.d. $95 \%$ & $5 \%$ \\
\hline
\end{tabular}

Dari data asumsi rentang umur aset dan sisa populasinya tersebut di atas, dengan menggunakan persamaan regresi (kecuali untuk pola standard) dihitung parameterparameter tertentu sesuai dengan bentuk pola distribusi yang diinginkan, yaitu:

\begin{tabular}{|l|ccccc|}
\hline \multirow{2}{*}{ Pola Distribusi } & \multicolumn{5}{|c|}{ Parameter } \\
\cline { 2 - 7 } & A & b & $\mu$ & $\alpha$ & $\beta$ \\
\hline Standard & - & - & - & - & - \\
\hline Linear & 0 & 100 & - & - & - \\
\hline Delayed Linear & 10.68 & 100 & - & - & - \\
\hline Logistic & - & - & 58,80 & - & 9.35 \\
\hline Weibull & - & - & - & 2.74 & 65.37 \\
\hline
\end{tabular}

Sementara itu, untuk asumsi metode depresiasi akan digunakan metode garis lurus (straight line method) dimana suatu aset disusutkan secara proporsional dalam periode tertentu dan nilai aset akan habis sesuai dengan asumsi umur asetnya. Pemilihan metode garis lurus ini dilakukan disamping karena relatif sederhana, tetapi juga karena telah digunakan di negara-negara maju. Secara empiris metode ini terbukti mampu mengestimasi nilai penyusutan yang mendekati kenyataan.

\section{Hasil Perhitungan Stok Kapital}

Berdasarkan penghitungan stok kapital dengan menggunakan data PMTB dan asumsiasumsi tersebut diatas, berikut ini data stok kapital disajikan menurut 3 (tiga) kelompok: Stok Kapital Bruto (GCS), Stok Kapital Neto (NCS) metode Australia, dan NCS metode 
Belanda. Ketiga kelompok data stok kapital tersebut disajikan atas dasar harga konstan tahun 1993.

Angka GCS menunjukkan nilai stok kapital atas dasar harga konstan tahun 1993 yang dalam konsep akuntansi GCS sering disebut sebagai nilai perolehan (carrying value). GCS menyajikan nilai barang modal setelah dikurangi sejumlah barang modal yang terdiscard dalam suatu periode tetapi sebelum dikurangi dengan nilai penyusutan barang modal tersebut. Sedangkan dalam konsep makro, nilai perolehan barang modal (GCS) identik dengan harga pembelian barang modal setelah dilakukan adjustment menggunakan harga pasar (market price). Sementara itu, angka NCS menunjukkan jumlah barang modal setelah dikurangi nilai penyusutannya, nilai barang modal yang ter-discard.

\section{PERKEMBANGANTOTALSTOK KAPITAL}

Selama kurun waktu 1980 - 2000, angka stok kapital menunjukkan perkembangan yang cukup signifikan sejalan dengan pembangunan ekonomi Indonesia. Pada tahun 1980, nilai stok kapital yang dihitung atas dasar harga konstan 1993 dan diestimasi dengan

Tabel 1. Perkembangan Total Stok Kapital

Tahun 1980 - 2000 (Rp Milyar)

\begin{tabular}{|c|c|r|r|r|}
\hline \multirow{2}{*}{ Pe riode } & \multicolumn{2}{|c|}{ S tok Kapital dengan P ola W eibull } \\
\cline { 3 - 5 } & & \multirow{2}{*}{ GC S } & \multicolumn{2}{|c|}{ NCS } \\
\cline { 3 - 5 } & & & Australia & B e landa \\
\hline 1 & 1980 & $992,084.9$ & $648,019.8$ & $695,244.1$ \\
3 & 1981 & $1,026,703.6$ & $680,721.0$ & $726,589.8$ \\
4 & 1982 & $1,065,389.6$ & $713,874.5$ & $759,715.0$ \\
5 & 1983 & $1,106,186.2$ & $745,859.7$ & $792,687.8$ \\
6 & 1984 & $1,137,321.9$ & $765,252.3$ & $814,249.2$ \\
7 & 1985 & $1,168,855.7$ & $783,262.1$ & $835,233.3$ \\
8 & 1986 & $1,203,154.2$ & $803,467.7$ & $858,260.3$ \\
9 & 1987 & $1,237,291.5$ & $823,096.6$ & $880,514.6$ \\
10 & 1988 & $1,276,660.4$ & $847,578.0$ & $907,394.9$ \\
11 & 1989 & $1,321,012.1$ & $876,529.0$ & $938,265.4$ \\
12 & 1991 & $1,371,705.1$ & $911,037.9$ & $974,475.7$ \\
13 & 1992 & $1,428,232.3$ & $949,763.0$ & $1,014,966.4$ \\
14 & 1993 & $1,483,924.5$ & $986,081.6$ & $1,053,472.9$ \\
15 & 1994 & $1,541,018.7$ & $1,022,489.3$ & $1,092,586.7$ \\
16 & 1995 & $1,605,952.4$ & $1,065,740.0$ & $1,138,554.5$ \\
17 & 1996 & $1,680,461.7$ & $1,117,282.6$ & $1,192,658.5$ \\
18 & 1997 & $1,766,441.7$ & $1,178,654.7$ & $1,256,665.6$ \\
19 & 1998 & $1,858,618.7$ & $1,243,375.2$ & $1,324,491.0$ \\
20 & 1999 & $1,899,356.3$ & $1,253,243.0$ & $1,339,983.9$ \\
21 & 2000 & $1,916,055.1$ & $1,238,855.1$ & $1,333,347.9$ \\
\hline
\end{tabular}


menggunakan pola Weibull tercatat sebesar Rp960.861,9 Milyar (GCS) atau sebesar Rp616.796,8 Milyar (NCS - Metode Australia). Sejak tahun 1980 nilai stok kapital Indonesia terus meningkat hingga mencapai hampir 2 (dua) kali lipat pada tahun 2000, yaitu sebesar Rp1.939.831,5 Milyar (GCS) atau sebesar Rp1.236.498,1 Milyar (NCS Metode Australia). Peningkatan nilai stok kapital tersebut disebabkan oleh meningkatnya jumlah investasi barang modal setiap tahun, perubahan harga dan peningkatan kualitas barang modal. Perkembangan total stok kapital Indonesia yang diestimasi menggunakan pola distribusi Weibull baik yang dihitung dengan metode Australia maupun Belanda terlihat dalam tabel 1 di bawah ini. Data hasil penghitungan stok kapital dengan pola distribusi lainnya secara lengkap dapat dilihat pada lampiran.

\section{PERTUMBUHAN INDEKSSTOKKAPITAL}

Angka indeks stok kapital (Capital Stock Index / CSI) menunjukkan gambaran mengenai pertumbuhan stok kapital per tahun. Dengan menggunakan tahun dasar 1979, secara garis besar angka CSI dengan pola Weibull terlihat menunjukkan pertumbuhan positif yaitu dari 103,25 menjadi 201,88 untuk GCS atau dari 105,06 menjadi 200,47 untuk NCS - Metode Australia. Pertumbuhan CSI rata-rata per tahun (yearly average) tercatat sebesar 3,41\% (GCS) atau 3,38\% (NCS - Metode Australia). Pertumbuhan NCS pada awal tahun 1980-an sekitar 5\% cenderung lebih tinggi dibandingkan pertumbuhan pada tahuntahun sesudahnya (1984 s.d. 1993) yang berkisar antara 2\% s.d. 4\%. Sejak tahun 1994, pertumbuhan NCS kembali mengalami peningkatan hingga mencapai 5,49\% (NCS Metode Australia) atau 5,40\% (NCS - Metode Belanda) pada tahun 1997. Namun demikian, krisis ekonomi yang terjadi sejak pertengahan tahun 1997 yang berdampak langsung terhadap iklim investasi di Indonesia menyebabkan turunnya stok kapital. Pertumbuhan NCS pada tahun 1998 merosot menjadi sebesar 0,79\% (NCS - Metode Australia) atau 1,17\% (NCS - Metode Belanda). Bahkan pada tahun 1999, angka stok kapital sempat mengalami pertumbuhan negatif sebesar -1,15\% (NCS - Metode Australia) atau $-0,05 \%$ (NCS - Metode Belanda). Hal ini terjadi karena adanya pengurangan pembelian barang modal baru sejak Indonesia mengalami krisis ekonomi, sementara nilai barang modal lama yang discard (usai pakai) maupun yang terdepresiasi terus bertambah. Pemulihan ekonomi yang berlansung pada tahun 2000 berdampak positif pada membaiknya iklim investasi di Indonesia. Hal ini dapat dilihat dari pertumbuhan stok kapital yang meningkat pada tahun 2000 dibandingkan tahun sebelumnya.

\section{PERKEMBANGAN DISTRIBUSISTOKKAPITAL}

Berdasarkan distribusinya, stok kapital Indonesia selama kurun waktu 20 tahun didominasi oleh kelompok Bangunan, Mesin, dan Transportasi. Dari data stok kapital neto (NCS) yang dihitung menggunakan pola Weibull metode Australia (Tabel 3), 
diketahui bahwa kelompok Bangunan mendominasi stok kapital Indonesia dengan kontribusi sebesar 59,98\% pada tahun 1980 dan terus meningkat menjadi 75,65\% pada tahun 2000. Sementara itu, kontribusi kelompok Transportasi mengalami penurunan yang drastis secara terus menerus selama 20 tahun dari 23,19\% (1980) menjadi hanya $3,94 \%$ (2000), meskipun dalam besaran nominal kelompok ini tetap mengalami peningkatan. Penurunan yang tajam pada kelompok Transportasi tersebut semata-mata disebabkan oleh kontribusi kelompok Bangunan yang meningkat sangat pesat. Dengan kata lain, pertumbuhan stok kapital kelompok Transportasi jauh lebih lambat dibandingkan akumulasi stok kapital kelompok Bangunan. Kelompok Mesin memberikan kontribusi yang cukup tinggi dengan rata-rata kontribusi selama 20 ahun terakhir sebesar $15,91 \%$. Peningkatan kontribusi secara pesat terjadi pada periode 1988 sampai dengan 1998 dengan rata-rata kontribusi sebesar 18\%, bahkan pernah mencapai lebih dari $20 \%$ pada tahun 1991 dan 1992. Pada saat terjadi krisis ekonomi, penurunan impor mesinmesin karena melemahnya berbagai kegiatan ekonomi menyebabkan kontribusi stok kapital kelompok Mesin turun menjadi 14,93\% (1999) dan 13,92\% (2000).

Tabel 2. Indeks dan Pertumbuhan Stok Kapital (\%)

\begin{tabular}{|c|c|c|c|c|c|c|c|}
\hline \multirow{3}{*}{\multicolumn{2}{|c|}{ Periode }} & \multicolumn{3}{|c|}{ Indeks Stok Kapita1Pola Weibull } & \multicolumn{3}{|c|}{ Pertumbuhan } \\
\hline & & \multirow{2}{*}{ GCS } & \multicolumn{2}{|c|}{$\mathrm{NCS}$} & \multirow{2}{*}{ GCS } & \multicolumn{2}{|c|}{$\mathrm{NCS}$} \\
\hline & & & Australia & Belanda & & A ustralia & Belanda \\
\hline 1 & 1980 & 103.25 & 105.06 & 104.54 & 3.25 & 5.06 & 454 \\
\hline 2 & 1981 & 106.85 & 110.36 & 109.25 & 3.49 & 5.05 & 451 \\
\hline 3 & 1982 & 110.88 & 115.74 & 114.23 & 3.77 & 4.87 & 456 \\
\hline 4 & 1983 & 115.12 & 120.92 & 119.19 & 3.83 & 4.48 & 434 \\
\hline 5 & 1984 & 118.36 & 124.07 & 122.43 & 2.81 & 2.60 & 2.72 \\
\hline 6 & 1985 & 121.65 & 126.99 & 125.58 & 2.77 & 2.35 & 258 \\
\hline 7 & 1986 & 125.22 & 130.26 & 129.05 & 2.93 & 2.58 & 2.76 \\
\hline 8 & 1987 & 128.77 & 133.45 & 132.39 & 2.84 & 2.44 & 259 \\
\hline 9 & 1988 & 132.87 & 137.42 & 136.43 & 3.18 & 2.97 & 3.05 \\
\hline 10 & 1989 & 137.48 & 142.11 & 141.08 & 3.47 & 3.42 & 3.40 \\
\hline 11 & 1990 & 142.76 & 147.70 & 146.52 & 3.84 & 3.94 & 3.86 \\
\hline 12 & 1991 & 148.64 & 153.98 & 152.61 & 4.12 & 4.25 & 4.16 \\
\hline 13 & 1992 & 154.44 & 159.87 & 158.40 & 3.90 & 3.82 & 3.79 \\
\hline 14 & 1993 & 160.38 & 165.77 & 164.28 & 3.85 & 3.69 & 3.71 \\
\hline 15 & 1994 & 167.14 & 172.79 & 171.19 & 4.21 & 4.23 & 421 \\
\hline 16 & 1995 & 174.89 & 181.14 & 179.33 & 4.64 & 4.84 & 4.75 \\
\hline 17 & 1996 & 183.84 & 191.09 & 188.95 & 5.12 & 5.49 & 537 \\
\hline 18 & 1997 & 193.43 & 201.59 & 199.15 & 5.22 & 5.49 & 5.40 \\
\hline 19 & 1998 & 197.67 & 203.19 & 201.48 & 2.19 & 0.79 & 1.17 \\
\hline 20 & 1999 & 199.41 & 200.85 & 200.48 & 0.88 & -1.15 & -0.50 \\
\hline 21 & 2000 & 201.88 & 200.47 & 201.02 & 1.24 & -0.19 & 027 \\
\hline
\end{tabular}




\section{PERBANDINGAN HASIL PERHITUNGAN STOK KAPITAL}

Dari hasil perhitungan (penghitungan stok kapital menggunakan 5 macam asumsi pola distribusi (Standard, Linear, Delayed Linear, Logistic, dan Weibull) yang dihitung dengan metode dari Australia dan Belanda) diperoleh angka stok kapital dengan besaran nilai yang berbeda-beda, namun memiliki pola trend yang relatif sama, kecuali stok kapital yang dihitung menggunakan asumsi pola distribusi Standard. Dengan menggunakan pola Standard, stok kapital dalam angka nominal (level) terlihat jauh lebih besar dibandingkan angka stok kapital yang dihitung menggunakan pola distribusi lainnya. Disamping itu, trend data yang diperoleh juga sedikit berbeda dibandingkan trend data dengan pola lainnya. Dengan menggunakan pola Linear, Delayed Linear, Logistic dan

Tabel 3. D istribusi Stok Kapital (N CS-A ustralia) Pola Weibull (\%)

\begin{tabular}{|c|c|c|c|c|c|c|c|}
\hline 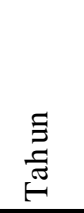 & $\begin{array}{l}\bar{\pi} \\
0 \\
ث\end{array}$ & 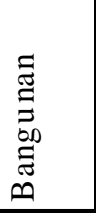 & $\begin{array}{l}\Xi \\
\stackrel{\Xi}{\infty} \\
\sum\end{array}$ & 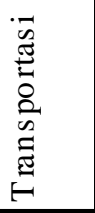 & 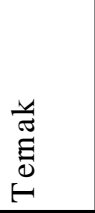 & 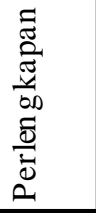 & 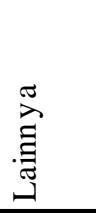 \\
\hline 1980 & 100 & 59.98 & 12.01 & 23.19 & 0.02 & 1.49 & 3.31 \\
\hline 1981 & 100 & 64.56 & 12.22 & 18.50 & 0.02 & 1.39 & 3.31 \\
\hline 1982 & 100 & 67.61 & 12.41 & 15.41 & 0.01 & 1.26 & 3.29 \\
\hline 1983 & 100 & 67.70 & 13.37 & 13.77 & 0.02 & 1.37 & 3.77 \\
\hline 1984 & 100 & 68.22 & 13.65 & 12.84 & 0.01 & 1.31 & 3.97 \\
\hline 1985 & 100 & 70.53 & 13.50 & 11.08 & 0.00 & 1.04 & 3.84 \\
\hline 1986 & 100 & 70.26 & 14.48 & 9.81 & 0.00 & 1.09 & 4.35 \\
\hline 1987 & 100 & 70.46 & 15.68 & 8.58 & 0.01 & 0.96 & 4.31 \\
\hline 1988 & 100 & 69.55 & 17.49 & 7.56 & 0.01 & 0.94 & 4.45 \\
\hline 1989 & 100 & 68.23 & 18.23 & 7.33 & 0.01 & 1.30 & 4.91 \\
\hline 1990 & 100 & 67.27 & 19.39 & 7.01 & 0.00 & 1.27 & 5.05 \\
\hline 1991 & 100 & 66.85 & 20.28 & 6.78 & 0.00 & 1.05 & 5.03 \\
\hline 1992 & 100 & 67.77 & 20.04 & 6.14 & 0.01 & 0.91 & 5.13 \\
\hline 1993 & 100 & 69.56 & 19.05 & 5.50 & 0.02 & 0.77 & 5.09 \\
\hline 1994 & 100 & 71.09 & 17.87 & 5.27 & 0.03 & 0.67 & 5.07 \\
\hline 1995 & 100 & 72.13 & 16.95 & 4.98 & 0.04 & 0.67 & 5.25 \\
\hline 1996 & 100 & 72.63 & 16.37 & 4.66 & 0.04 & 0.77 & 5.53 \\
\hline 1997 & 100 & 72.68 & 16.09 & 4.74 & 0.05 & 0.83 & 5.61 \\
\hline 1998 & 100 & 72.61 & 16.17 & 4.47 & 0.05 & 0.92 & 5.79 \\
\hline 1999 & 100 & 74.63 & 14.93 & 3.96 & 0.04 & 0.88 & 5.57 \\
\hline 2000 & 100 & 75.65 & 13.92 & 3.94 & 0.03 & 0.93 & 5.53 \\
\hline
\end{tabular}


Weibull, terlihat bahwa pada tahun 1998s.d. 2000 terjadi pelambatan bahkan penurunan stok kapital yang sesuai dengan fenomena yang terjadi pada saat itu, dimana kegiatan investasi melemah padasaat krisis ekonomi. Fenomenatersebut tidak dapat ditunjukkan dengan data stok kapital yang dihitung dengan asumsi pola Standard.
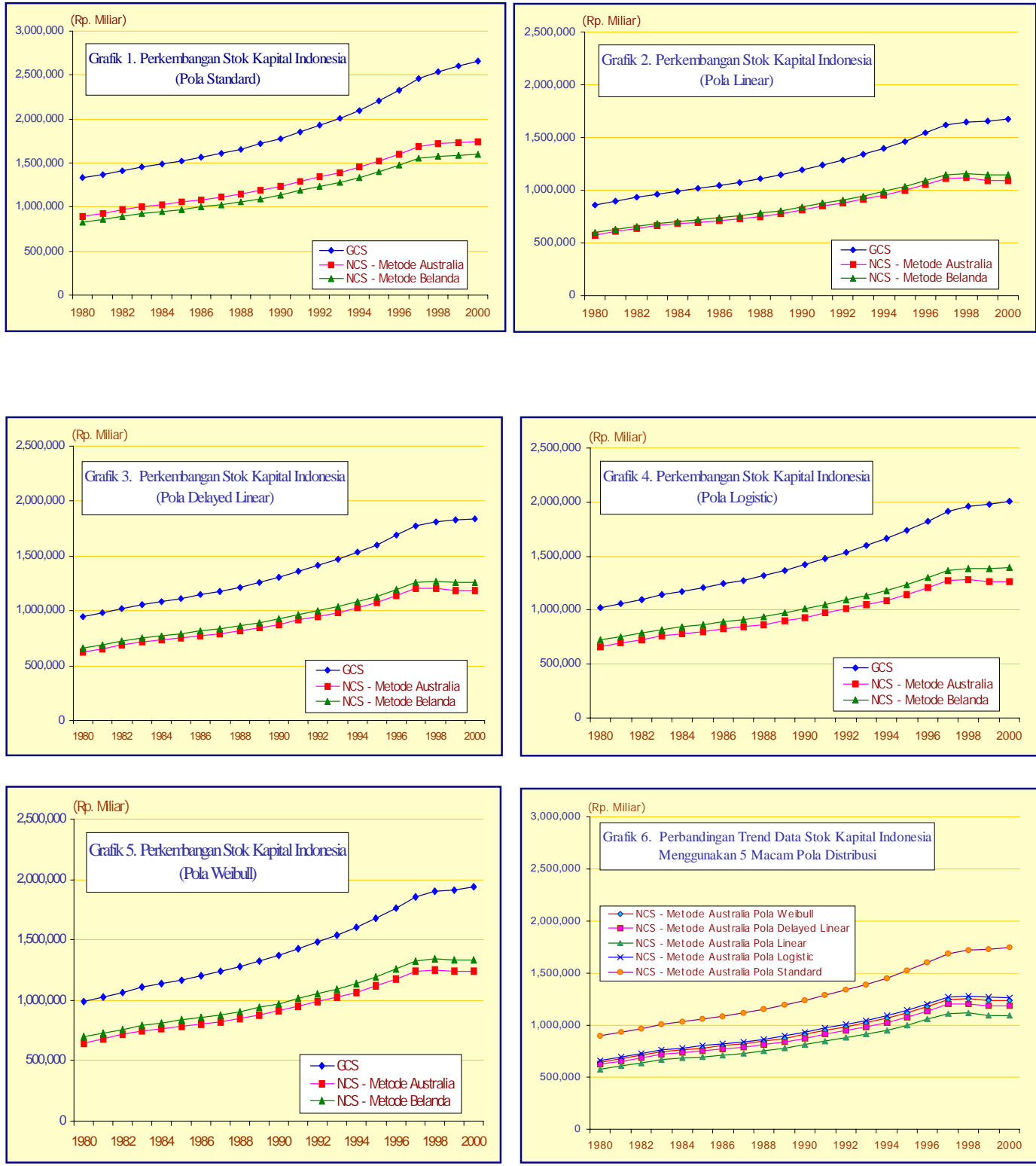


\section{PENUTUP}

\section{Kesimpulan}

Kegiatan penghitungan stok kapital ini merupakan penelitian lanjutan dari hasil kajian stok kapital yang dilakukan tahun 2000 yang merekomendasikan dilakukannya penghitungan stok kapital dengan metode PIM. Berdasarkan hasil perhitungan stok kapital tersebut, dapat ditarik kesimpulan sebagai berikut:

1. Penghitungan stok kapital dengan menggunakan metode PIM dilakukan dengan cara mengakumulasikan data investasi (PMTB) dengan mempertimbangkan asumsi umur aset, pola distribusi umur aset, dan metode depresiasi yang digunakan, serta dihitung dengan metode Australia (discard function) dan metode Belanda (survival function). Penghitungan stok kapital didasarkan pada konsep 'wealth', yaitu suatu konsep dimana stok kapital menunjukkan kekayaan berupa barang modal suatu negara. Data tersebut disajikan dalam 2 (dua) konsep, yaitu stok kapital bruto (Gross Capital Stock/GCS) dan stok kapital neto (Net Capital Stock/NCS), serta disusun secara time-series untuk periode 1980-2000.

2. Simulasi perhitungan stok kapital dengan menggunakan 5 macam pola distribusi umur aset dan 2 metode perhitungan (Australia dan Belanda) menghasilkan berbagai variasi angka stok kapital yang berbeda secara nominal (level), namun dengan pola atau trend data yang relatif sama. Secara indikatif, data stok kapital menunjukkan trend yang cukup relevan dengan perkembangan ekonomi, antara lain tercermin dari melambatnya pertumbuhan stok kapital sejak terjadinya krisis ekonomi.

3. Asumsi pola distribusi yang digunakan menghasilkan perbedaan angka stok kapital yang tidak terlalu besar, kecuali pola distribusi Standard. Berdasarkan penelitian di negara lain juga disimpulkan hal yang sama, bahkan disebutkan bahwa pola Standard dianggap kurang realistis sehingga penggunaan pola distribusi ini tidak direkomendasikan.

4. Dilihat dari prosedur dan mekanisme penghitungan yang dilakukan, asumsi umur aset diperkirakan lebih berpengaruh terhadap hasil perhitungan stok kapital dibandingkan asumsi pola distribusi. Kesimpulan ini telah diuji kebenarannya dalam sebuah penelitian mengenai metode PIM yang dilakukan di Belanda oleh Gerhard Meinen pada tahun 1998. 


\section{Rekomendasi dan Saran}

Berbagai macam pendekatan diupayakan untuk memperoleh angka stok kapital yang reliable agar nantinya benar-benar dapat dimanfaatkan untuk kepentingan penelitianpenelitian ekonomi makro. Upaya tersebut telah diwujudkan dengan memperbaiki asumsiasumsi dan metode yang digunakan dalam penghitungan stok kapital. Penyusunan data stok kapital dengan metode PIM memiliki konsekuensi ketergantungan pada asumsi yang digunakan. Semakin baik asumsi yang digunakan, maka data yang dihasilkan juga akan semakin reliable.

Dari hasil perhitungan stok kapital, diperoleh 15 macam angka stok kapital yang disebabkan karena perbedaan asumsi pola distribusi dan metode yang digunakan. Ke-15 macam angka stok kapital tersebut terdiri dari 5 angka GCS, 5 angka NCS Metode Australia dan 5 angka NCS Metode Belanda. Untuk memberikan rekomendasi mengenai data stok kapital yang dapat dimanfaatkan, diperlukan penelitian lebih lanjut. Meskipun demikian, berdasarkan data yang diperoleh bahwa angka-angka stok kapital yang dihasilkan memiliki pola atau trend yang relatif sama (kecuali pola Standard), maka pemanfaatannya dalam penyusunan suatu model ekonomi tergantung pada konsistensi data yang digunakan.

Dari angka-angka stok kapital yang ada, kami merekomendasikan angka stok kapital yang diperoleh melalui pendekatan pola distribusi Weibull dan dihitung dengan metode Australia. Angka ini kami rekomendasikan karena asumsi yang digunakan lebih mendekati keadaan yang sebenarnya. Disamping itu, dari plot data yang dilakukan angka stok kapital dengan pola Weibull menunjukkan level rata-rata dari angka-angka stok kapital lainnya.

Dalam upaya penyempurnaan kualitas data stok kapital di masa yang akan datang, berikut ini saran-saran perbaikan yang perlu dilakukan:

1. Pengujian data stok kapital dengan menggunakan benchmark berupa besaran-besaran ekonomi makro lainnya seperti PDB, PMA/PMDN, data ekspor impor, dan indeks produksi.

2. Untuk menyempurnakan asumsi yang digunakan, terutama asumsi umur aset dan pola distribusi, diperlukan survei-survei khusus yang secara langsung mengamati eksistensi barang modal pada perusahaan-perusahaan, lembaga pemerintah dan rumah tangga.

3. Survei-survei khusus tersebut diatas dapat dimanfaatkan pula untuk melakukan identifikasi terhadap produktifitas barang modal, sehingga diperoleh data stok kapital yang produktif (Productive Capital Stock). Data ini sangat diperlukan untuk tujuan penelitian yang lebih komprehensif, antara lain dalam rangka membangun suatu model ekonomi makro. 
4. Untuk mengantisipasi perubahan acuan penyusunan PDB dengan konsep SNA 1993, maka penyusunan data PMTB sebagai bahan dasar penyusunan data stok kapital dengan metode PIM harus mulai disesuaikan.

5. Dalam jangka panjang, penyusunan data stok kapital dengan metode PIM perlu diperbaiki dengan metode lainnya seperti Fixed Asset Accounting Simulation Model (FAASM) yang saat ini telah dikembangkan di Canada. Metode ini dilakukan dengan cara mengamati secara langsung data barang modal yang dicatat dalam laporan keuangan perusahaan. Dilihat dari prosedur dan mekanismenya, implementasi metode FAASM di Indonesia nampaknya dapat dilaksanakan.

\section{REFERENSI}

Ariantoro, Eko (2001), Penetapan Asumsi dalam Perhitungan Stok Kapital, Bagian Statistik Sektor Riil dan Keuangan Pemerintah, Bank Indonesia.

Australia Bureau of Statistics (1997), Australia's Methodology for Compiling Estimates of Capital Stock and Consumption of Fixed Capital, Background Paper of Capital Stock Conference in Canberra.

Badan Pusat Statistik (1997), Estimation of Capital Stock and Investment Matrix In Indonesia, Background Paper of Capital Stock Conference in Canberra.

(1995), Study of Estimation of Capital Stock in Indonesia 1979-1994, Jakarta.

Tabel Input Output, berbagai seri, Jakarta

Bagian Statistik Sektor Riil dan Keuangan Pemerintah (2000), Kajian Kemungkinan Pengumpulan Data Stok Kapital Sektor Industri Pengolahan, Direktorat Statistik Ekonomi dan Moneter, Bank Indonesia.

Bagian Statistik Sektor Riil dan Keuangan Pemerintah (2001), Draft Stok Kapital, Hasil Kerjasama Direktorat Statistik Ekonomi dan Moneter, Bank Indonesia dengan Badan Pusat Statistik. 
Bagian Statistik Sektor Riil dan Keuangan Pemerintah (2001), Proses Pengumpulan Matriks Pembentukan Modal Tetap Bruto (PMTB), Hasil Kerjasama Direktorat Statistik Ekonomi dan Moneter, Bank Indonesia dengan Badan Pusat Statistik.

Divisi Pengembangan Statistika dan Komputasi (2001), Materi Workshop: Probabilitas dan Distribusi, Fakultas MIPA, Institut Pertanian Bogor.

Frenken, Jim (1992), How to Measure Tangible Capital Stock?: The Choice Between Two Methods, CBS Netherlands.

Keuning, Steven J. (1988), An Estimate Of Fixed Capital Stock By Industry and Type Of Capital Good in Indonesia, Statistical Analysis Capability Programme, Working Paper Series No. 4, Jakarta.

Saleh, Kusmadi (1997), The Measurement of Gross Domestic Fixed Capital Formation in Indonesia, Paper of Capital Stock Conference in Canberra.

Meinen, Gerhard (1999), Measuring Capital Stock: Explanatory Notes for the Manual on Capital Stock Statistics, Statistics Netherlands.

Meinen, Gerhard and Bert Verlinden (1997), Statistics on Tangible Capital Stock: Direct Observation at Statistics Netherlands, Paper of Conference on Capital Stock (Preliminary Version) in Canberra.

Meinen, Gerhard, Piet Verbiest and Peter-Paul de Wolf (1998), Perpetual Inventory Method: Service Lives, Discard Patterns and Depreciation Methods, Department of National Accounts, Statistics Netherlands.

Timmer, Marcel, The Dynamics of Asian Manufacturing: A Comparative Perspective, 19631993, Eindhoven Centre for Innovation Studies, Netherlands.

Timmer, Marcel (1999), Indonesia's Ascent on The Technology Ladder: Capital Stock and Total Factor Productivity in Indonesian Manufacturing, 1975-95, Bulletin of Indonesian Economic Studies, Eindhoven University of Technology, Netherlands.

Wicaksono, Gunawan (2001), Perhitungan Stok Kapital: Beberapa Pengamatan terhadap Model Perhitungan Stok Kapital dengan Perpetual Inventory Method Metode Australia dan Metode Belanda, Bagian Statistik Sektor Riil dan Keuangan Pemerintah, Bank Indonesia. 


\section{APPENDIX}

\section{KLASIFIKASI BARANG MODAL}

1. Klasifikasi menurut 6 Kelompok dan 34 Jenis Barang Modal

Yaitu penggolongan barang modal menurut komponen penggunaan PDB yang telah dimodifikasi secara rinci mengikuti penggolongan dalam tabel I-O. Untuk memudahkan dalam melakukan analisis penggolongan stok kapital maka klasifikasi jenis barang modal yang dibentuk adalah:

a. Bangunan

a.1. Bangunan tempat tinggal

a.2. Bangunan bukan tempat tinggal

a.3. Bangunan lainnya:

- Prasarana pertanian

- Jalan, jembatan dan pelabuhan

- Bangunan dan instalasi listrik, gas, air minum dan komunikasi

- Bangunan lainnya

b. Mesin

b.1. Mesin penggerak mula

b.2. Mesin dan perlengkapannya

b.3. Mesin pembangkit dan motor listrik

b.4. Mesin listrik dan perlengkapannya

c. Sarana transportasi

c.1. Kapal dan jasa perbaikannya

c.2. Kereta api dan jasa perbaikannya

c.3. Pesawat terbang dan jasa perbaikannya

c.4. Kendaraan bermotor kecuali sepeda motor 
c.5. Sepeda motor

c.6. Alat pengangkutan lainnya

d. Ternak dan hasil-hasilnya

e. Perlengkapan

e.1. Listrik

- Alat listrik untuk rumahtangga

- Perlengkapan listrik lainnya

e.2. Barang dari logam

- Alat-alat dapur, pertukangan dan pertanian dari logam

- Perabot rumahtangga dan kantor dari logam

- Barang-barang logam lainnya

e.3. Barang dari kain dan dari kulit

- Tekstil jadi kecuali pakaian

- Permadani, tali dan tekstil lainnya

- Barang-barang dari kulit lainnya

f. Lainnya

f.1. Perabot rumahtangga dari kayu, bambu dan rotan

f.2. Keramik dan barang-barang dari tanah liat

f.3. Kaca dan barang-barang dari kaca

f.4. Barang-barang lainnya dari bahan bukan logam

f.5. Barang-barang elektronik, komunikasi dan perlengkapannya

f.6. Alat ukur, fotografi, optik dan jam

f.7. Alat-alat musik

f.8. Alat-alat olahraga

f.9. Jasa perbengkelan lainnya (kendaraan bermotor dan tidak bemotor, alat-alat elektronik, perlengkapan listrik, perbaikan mesin dan sejenisnya) 


\section{Klasifikasi menurut Lapangan Usaha/Sektor Ekonomi Pengguna}

Penggolongan ini dimaksudkan untuk mengklasifikasikan jenis barang modal yang dimiliki atau dikuasai oleh sektor ekonomi (capital user) tertentu untuk digunakan dalam proses produksinya, yaitu:

a. Pertanian, peternakan, kehutanan dan perikanan

b. Pertambangan dan penggalian

c. Industri manufaktur

c.1. Industri makanan, minuman dan tembakau

c.2. Industri teksti dan kulit

c.3. Industri barang dari kayu, bambu dan sejenisnya

c.4. Industri kertas dan percetakan

c.5. Industri kimia (tidak termasuk pengilangan)

c.6. Industri pengilangan dan industri mineral bukan logam

c.7. Industri logam dasar

c.8. Industri barang-barang dari logam

c.9. Industri lainnya

d. Listrik, gas, dan air bersih

e. Bangunan

f. Perdagangan, hotel dan restoran

g. Pengangkutan dan komunikasi

h. Lembaga keuangan, jasa perusahaan, real estat

i. Pemerintahan Umum

j. Jasa-jasa

\section{Klasifikasi menurut Institusi atau Pelaku Ekonomi}

Penggolongan barang modal ini lebih menjelaskan tentang komposisi barang modal yang dikuasai/dimiliki atau dioperasikan oleh pelaku-pelaku ekonomi (institusi). Istilah 
institusi tersebut diperkenalkan dalam SNA 1993 sebagai unit-unit usaha penting yang memiliki (menguasai) aset serta mampu menciptakan kewajiban dengan berbagai aktivitas ekonomi, serta melakukan transaksi dengan unit-unit ekonomi lainnya. Pelaku ekonomi tersebut digolongkan menurut organisasi penyelenggaraan kegiatan ekonomi suatu negara yang terbagi atas 3 kategori yaitu:

\section{a. Pemerintah}

Pemerintah adalah unit ekonomi penyelenggara pemerintahan umum (general administration) baik pemerintah pusat maupun daerah. Pengeluaran barang modal disini mencakup antara lain pengeluaran untuk pembangunan gedung kantor, pembangunan rumah dinas, gedung sekolah, rumah sakit dan Puskesmas, jalan dan jembatan, prasarana fisik lainnya, pembelian kendaraan dinas, pembelian mesin tik, mesin komputer dan sebagainya.

\section{b. Badan Usaha Milik Negara (BUMN) dan Badan Usaha Milik Daerah (BUMD)}

Unit ekonomi ini menguasai barang modal seperti lapangan terbang, pelabuhan laut, satelit, jalan tol, jaringan telekomunikasi, industri senjata, kereta api baik industri maupun jaringan transportasinya, armada bus dan truk, pesawat udara, kapal laut, jaringan dan distribusi air minum, jaringan listrik dan sebagainya.

\section{c. Badan usaha swasta dan rumah tangga,}

Unit ekonomi ini menguasai barang modal seperti bangunan kantor, pabrik, gudanggudang penyimpanan, peralatan kantor, mesin-mesin, kendaraan (sarana transportasi) dan sebagainya.

\section{Klasifikasi menurut Sumber atau Wilayah Asal Barang Modal}

Penggolongan ini dimaksudkan untuk mengklasifikasikan barang modal menurut sumber atau wilayah asal barang modal yang dikuasai/dimiliki oleh berbagai sektor dan institusi di dalam negeri, yang terbagi atas:

a. Produksi Domestik

Yaitu barang modal baru yang berasal dari produksi dalam negeri (wilayah domestik suatu negara).

b. Produksi Negara Lain (impor),

Yaitu barang modal yang berasal dari hasil produksi luar negeri, baik barang baru maupun bekas. 
Penggolongan ini dimaksudkan untuk melihat perbandingan pangsa barang modal yang benar-benar mampu dihasilkan oleh produsen domestik, maupun yang masih harus didatangkan dari luar negeri. Impor menunjukkan masih adanya ketergantungan terhadap produk yang berasal dari negara lain (impor leakages). Jenis barang modal yang dihasilkan di dalam negeri bisa sama dengan yang berasal dari impor, selama penyediaan yang ada tidak mampu untuk memenuhi permintaan domestik 